University of Wollongong

Research Online

Faculty of Business - Papers (Archive)

Faculty of Business and Law

$1-1-2015$

Ownership characteristics and earnings management in China

Fei Guo

Zhongnan University of Economics and Law

Shiguang Ma

University of Wollongong, shiguang@uow.edu.au

Follow this and additional works at: https://ro.uow.edu.au/buspapers

Part of the Business Commons

Research Online is the open access institutional repository for the University of Wollongong. For further information contact the UOW Library: research-pubs@uow.edu.au 


\title{
Ownership characteristics and earnings management in China
}

\begin{abstract}
Chinese firms are characterized by multiple ownership and high ownership concentration. In this research, we conduct an intensive investigation into the determination of ownership characteristics in earnings management behaviors for Chinese domestic listed firms. Our results indicate that earnings management is determined by the motivations of different types of ownerships. In particular, when a state agency is the largest owner, firms are less likely to undertake earnings management, although the state ownership ratio is positively associated with earnings management. Tradable ownership and particularly concentrated tradable ownership reduce earnings management, while total ownership concentration fosters earnings management.
\end{abstract}

\section{Keywords}

management, china, earnings, characteristics, ownership

Disciplines

Business

\section{Publication Details}

Guo, F. \& Ma, S. (2015). Ownership characteristics and earnings management in China. The Chinese Economy: translation and studies, 48 (5), 372-395. 


\title{
This article originally published as
}

Ownership characteristics and earnings management in China

\section{The Determination of Ownership Characteristics on Earnings}

\section{Management in China}

\author{
Fei Guo
}

School of Accounting, Zhongnan University of Economics and Law

No.182 Nanhu Ave, East Lake High-tech Development Zone, Wuhan, Hubei 430073, China

Tel: +86 27 88386570, Fax: +86 27 88386515, E-mail: fei guo@znufe.edu.cn

Shiguang Ma (Corresponding author)

School of Accounting and Finance, University of Wollongong

Northfields Avenue, Wollongong, NSW 2522, Australia

Tel: +61 2 42213312, Fax: +61 2 4221 4297, E-mail: shiguang@uow.edu.au 


\title{
The Determination of Ownership Characteristics on Earnings
}

\section{Management in China}

\begin{abstract}
Chinese firms are characterised with multiple ownership types and high ownership concentration. In this research, we conduct an intensive investigation into the determination of ownership characteristics in earnings management behaviours for Chinese domestic listed firms. Our results indicate that earnings management is determined by the motivations of different types of ownerships. In particular, when a state agency is the largest owner, firms are less likely to undertake earnings management, although the state ownership ratio is positively associated with the earnings management. Tradable ownership and particularly concentrated tradable ownership reduce earnings management, while total ownership concentration fosters earnings management.
\end{abstract}

Keywords: earnings management, ownership, ownership concentration, state, China JEL Classification: G32, G39, M40, M41 


\section{Introduction}

Earnings are an important performance measure of companies. Earnings management is a pervasive phenomenon in firms' financial reporting and their release of earnings-related information. In earnings management, managers use discretion in financial reporting and in structuring transactions, and thus, often the reported earnings diverge from the true economic performance of the company.

A large body of work has been developed in earnings management research. One stream concerns the consequence of earnings management. Francis et al. (2004) investigate equity cost of capital in relation to earnings management, and find that earnings management distorts earnings quality; and thereby, earnings quality is negatively associated with the equity cost of capital. Easley and O'Hara (2004) state that earnings management introduces information asymmetry and uninformed investors must be compensated with a risk premium. Leuz et al. (2003) indicate that earnings management conceals firm performance from outsiders, and thus earnings management decreases investor protection.

Other stream of research on earnings management concentrates on the determination of earnings management; that is, what motivations and factors lead a firm's manager to manipulate earnings. Dechow et al. (1996) find that earnings-manipulated firms usually have higher leverage ratios and are more likely to avoid debt covenants during and after the manipulation period than control firms. Both Scholes et al. (1992) and Maydew (1997) show that companies timing revenues and expense recognition to take advantage of lower tax rates or defer income in anticipation of a change to a lower tax rate. Other studies (Hayn, 1995; Dechow et al., 2003; Beaver et al., 2007) indicate that companies manage earnings for 'target beating' to meet analysts' forecasts and contractual income levels, or to avoid an inverse earnings trend that may lead to negative market feedback. 
Recently, the investigations on the relationship between earnings management, corporate governance and ownership structure remain high. According to some, 'better' corporate governance, such as more independent directors and effective monitoring, reduces the likelihood of fraud (Farber, 2005; Joe and Vandervelde, 2007). For others, CEO turnover, high audit committee quality and the separation of CEO and board chair mitigate earnings management behaviour (Doyle et al., 2007b; Vafeas, 2005; Farber, 2005). Some studies suggest that greater managerial ownership has an entrenchment effect - managers expropriate private benefits through their choice of accounting method (Smith, 1976; Dhaliwal et al., 1982).

Earnings management is pervasive activity for Chinese publically listed firms, which has attracted increasing studies. Firth et al. (2007) examine the informativeness of earnings for Chinese firms listed on the market from 1998 to 2003. They find that firms with highly concentrated share ownership have lower earnings informativeness. Foreign shareholders and the high percentage of tradable shares appear to enhance the earnings-returns relation. Independent directors, but the board size and the number of board meetings, are negatively associated with the magnitude of absolute discretionary accruals. Liu and Lu (2007) investigate the relation between earnings management and corporate governance using a sample of Chinese listed firms from 1999 to 2005. They show that good corporate governance mitigate earnings management. They find that the ownership of the first top shareholders has positive, while the ownership of remaining large shareholders from top 2 to top 10 has negative relation with earnings management. Wang and Yung (2011) study a sample of Chinese firms for the period 1998 - 2006 and find that earnings management is lower in state owned enterprise than private owned firms. Xu et al. (2012) employ a naïve method to test the relations between ownership type and earnings quality for Chinese publicly listed firms commencing 1999 through 2006. They document that private controlled firms, 
foreign invested firms and society owned firms outperform the state controlled firms in earnings quality.

Our research applies a relatively recent sample of Chinese listed firms from 2004 to 2010 and focuses on how ownership characteristics determine earnings management incentives. Our research has two significant differences from prior studies on the relations between ownership and earnings management of Chinese listed firms. First, we intensively test the impact of ownership characteristics on earnings management behaviour, including foreign ownership, state ownership, tradable ownership, institution ownership, managerial ownership. The existing literature normally examines one or a couple of the above ownership types interactively with corporate governance issues (Firth et al., 2007; Wang and Yung, 2011; Wang and Campbell, 2012). Although Xu et al. (2012) refer a set of ownership types, their ownership types are categorised mainly different from ours. Second, the novelty in our research is that we define two types of ownership concentration: total ownership concentration and tradable ownership concentration. Because of the fact that majority of top owners are non-tradable shareholders for many firms, we suspect that the tradable ownership concentration has different determination from total ownership concentration on earnings management. Ownership concentration is an important concern in existing research on earnings management, but is measured only as total ownership concentration (Firth et al., 2007; Liu and Lu, 2007; Ding et al., 2007)

Our empirical results show that total ownership concentration fosters earnings manipulation, while tradable ownership concentration resists earnings management. We find that firms whose largest owner is the state are less likely to manipulate earnings, although the ratio of state ownership is positively associated with earnings management on average. Foreign investors are unable to restrain firm's earnings management, while managerial 
ownership appears positively related to earnings management. In addition, institutional ownership by fund companies has insignificant impacts on earnings management.

The remaining part of this paper is structured as follows: Section 2 reviews relevant literature and develops hypotheses; Section 3 explains the data and defines variables; Section 4 is the description of statistics; Section 5 is the regression analyses and Section 6 concludes the paper.

\section{Ownership Characteristics and Hypothesis Development}

\subsection{Ownership Characteristics}

China's companies have multiple ownership types and unique ownership characteristics that differ from other countries. First, common shares sold publicly in the domestic market to Chinese residents are called 'A shares', while those sold initially to foreign investors are called 'B shares'. B shares have been accessible by Chinese residents since the restriction was removed in April 2001. H shares are those issued by China's companies and traded on the Hong Kong Stock Exchange. This research only includes firms that issued A shares, or A shares and B shares, and/or $\mathrm{H}$ shares.

Second, a large proportion of shares are publicly non-tradable. The initial purpose for Chinese government to establish a stock market was to raise capital rather than a thorough reform for a pure market drawn economy. Thus, the founders of many companies maintain ownership control by holding a large proportion of non-tradable shares. Even though the proportion of non-tradable shares has reduced due to financial market reforms, the proportion is still high, at 39 percent on average from 2004 to 2010.

Third, state ownership has remained high because many publicly listed firms were carved out or spun off from existing state enterprises. The state is the ultimate controlling shareholder or the largest shareholder for many listed firms. In recent years, the listing of 
non-state owned companies has increased. Such companies are called private firms or civilian firms in the literature, and are ultimately controlled by non-government units, including individuals, collective enterprises, and social entities.

Fourth, the ownership of China's listed firms is highly concentrated. This high level of ownership concentration has not only resulted from the many listed firms that were carved out from state enterprises, where the state retains a large proportion of shares, but also through family founder's private firms that preferred to maintain their controlling ownership. In particular, the ownership concentration in China can be categorized as total ownership and tradable ownership concentration. The large tradable shareholders and non-tradable shareholders have various motivations in earnings management.

Fifth, institutional ownership is relatively low in China, and is mainly held by fund companies. However, institutional ownership represents specialist management of shares, and thus is different from individual shareholders in monitoring of firms. Finally, the managerial ownership has been recognized by Chinese authority in recent years. An increasing number of firms have awarded shares to managers or have included shares in managers' remunerations. Although the amount of managerial ownership of China's listed firms is small, it may have observable influence on firm's management decision.

\subsection{Hypothesis Development}

China's firms issue A shares to domestic investors, while some also issue shares to foreign investors such as B shares and H-shares. Foreign investors are usually perceived to be more knowledgeable and sophisticated than domestic investors in terms of investment experience and the ability to collect, process, and analyse value-relevant information (Gul et al., 2010). However, foreign ownership is only about 8.63 percent of total shares outstanding on average. Thus foreign investors may be unable to monitor the firms effectively. 
The regulatory requirements for information disclosure for firms with foreign shareholders differ from those for firms with only domestic shareholders. Firms that exclusively issued A shares are required to prepare financial reports in accordance with domestic accounting standards (DAS). In contrast, A-share firms that simultaneously issued B shares or $\mathrm{H}$ shares were required to provide financial reports based on both the DAS and International Financial Reporting Standards (IFRS), or based on both DAS and Hong Kong Generally Accepted Accounting Principles (GAAP) (Gul et al., 2010; Wang, 2010).

Investors may recognize that the IFRS and GAAP, rather than DAS, enhance information transparency. Therefore, firms with foreign investment should engage in less earnings management. However, because the DAS and IFRS and DAS and GAAP are inconsistent in some parts, in order to produce financial report that comply with two accounting standards, earnings management may be used to a certain extent, although this type of earnings management may not break accounting rule. Thus we present our first hypothesis:

H1. Firms with foreign investment in $\mathrm{B}$ shares or $\mathrm{H}$ shares may have more incentives to manage earnings than firms with only domestic investment in A shares.

The function of state ownership is always in debate. Most studies examine the relationships between state ownership and firm value. According to resource-based theory, state-owned firms have advantages in their access to resources, tax benefits and a secured operation environment, which all add to the value of state-owned firms (Ma et al., 2010; Sun et al., 2002). In contrast, according to agency theory, state-owned firms have the burden of social responsibility and political objectives, such as maintaining employment and satisfying government annual revenue goals. Therefore, state-owned firms would not be able to make optimal decisions and this decreases their value (Gunasekarage et al., 2007; Wei et al., 2005). 
Several studies referring the relation between state ownership and earnings management of Chinese listed firms provides mixed arguments. Chen et al. (2008) document that state assists earnings management exists only in firms controlled by local governments, because local governments are more likely to provide subsidies for the firms for achieving listing requirements. Wang and Yung (2011) indicate that the protection to state owned firms by the government leads to a different incentive structure in state enterprises, which in turn, results in lower levels of earnings management.

We posit a different argument that the state ownership of a firm can be owned by various state agencies, such as State Asset Management Bureaus, SOEs affiliated to the central government, and SOEs affiliated to local government respectively; alternatively, the state ownership of a firm can be owned by different state entities. In the situation that state shares are owned by several owners and each owner has its own interest and non-economic concerns, state owned firms may conduct more earnings management. However, when a state agency is the largest owner of a firm, the firm is normally in key industries and dominates relevant production or service. Because of the support from government, this type of firms possesses advantages in access to resources and markets. Managers also tend to be politically connected and political promotion is a type of compensation parallel to salary and bourns. Managers of those firms have less incentives and necessary to manage earnings. Thus, we present our second hypothesis:

H2: State ownership is positively related to earnings management unless a state agency is the largest shareholder of the firm, in which earnings management incentives and necessity are mitigated.

Gedajlovic et al. (2005) classify shareholders into three categories: 'stable investors,' 'market investors,' and 'inside investors.' Each of these has a relatively distinct investment objective. The stable investors comprise affiliated firms, banks and insurance companies. 
Stable investors are willing to keep the ownership, primarily to cement and grow stable business relationships, rather than to earn returns on their equity investment. Market investors are 'pure investors,' in that they are typically tied to the firm by their equity stakes, and have maximizing equity returns as their primary investment objective.

Ma et al. (2010) use the two concepts of 'stable investors' and 'market investors' to explain the ownership of China's listed firms. The holders of non-tradable shares are definitely stable investors, because their shares are not tradable on stock exchanges. However, if the share price changes, the stable investors have no other choice but to hold onto the shares. It is true that one of the objectives of state and legal person non-tradable shareholders is to maintain control and involvement in the firms. In contrast, the holders of tradable shares are market investors who have the exclusive objective of maximizing returns.

Heugens et al. (2009) argue that firms may be sensitive to the pressures of market investors for two reasons. First, market investors will be more willing to sell their ownership stake when they are dissatisfied with the firm's performance. Selling off a large number of shares is a powerful disciplining force, since it is likely to decrease the firm's share price and thus increase the cost of equity capital. Second, market investors will require a risk premium when they fear problems such as tunnelling (expropriating firm assets) or opportunistic earnings management, which increases the firm's cost of equity capital. These disciplinary forces make it more likely that the firm's managers will engage in strategies consistent with the investment objectives of market investors, and mitigate the likelihood of opportunistic earnings management. Thus we present our third hypothesis:

H3: The tradable ownership ratio is negatively associated with earnings management due to the disciplining power of selling shares.

Dispersed ownership structure is usually observed in Anglo-Saxon countries, such as the US and UK. In other developed and developing countries, ownership is relatively 
concentrated, because firms are usually controlled by founding families and/or government, such as in Japan, Hong Kong, South Korea, Taiwan, and China. Leuz et al. (2003) find less earnings management occurred in companies in countries with dispersed ownership, strong investor rights, and legal enforcement. Heugens et al. (2009) state that ownership concentration is an efficient corporate governance strategy in markets with poor legal protection of minority shareholders.

The majority of empirical research asserts that concentrated ownership provides block holders with both incentives and power in monitoring firms to improve quality decisions, implying less opportunity for earnings management (Yeo et al., 2002; Jiraporn and Gleason, 2007). Princus et al. (2007) find accrual anomalies resulting from earnings management are negatively associated with share ownership concentration. However, some studies suggest that greater ownership concentration by managerial and family ownership has an entrenchment effect: managers extrapolate private benefits through their accounting method choice (Smith, 1976; Dhaliwal et al., 1982). Haw et al. (2004) provide evidence that firms with a larger concentration of control on cash flow rights engage in higher levels of earnings management. Leuz (2006) demonstrates that ownership concentration is positively associated with the level of earnings management.

Maug (1998) documents a theory of lock-up effect and liquidity effect to describe the relationship between ownership concentration and monitoring. In the lock-up effect, an increase in the degree of ownership concentration strengthens large shareholders' incentives to monitor the firm's management, because owning a larger stake makes the return on the firm's shares more significant for the large shareholders. In the liquidity effect, if a large proportion of total shares is owned by the large shareholders, then fewer shares are held by minority shareholders, meaning there is less liquidity in the shares. This occurs, because lack of liquidity means that small shareholders have a free ride on the effort of large shareholders, 
and the incentives of large shareholders to monitor the firm decreases. Alternatively, large shareholders may force managers to manipulate earnings to expropriate minority shareholders' wealth.

Shares listed in China's domestic market comprise tradable and non-tradable shares; thus, concentrated ownership can be measured by total ownership concentration and tradable ownership concentration. With respect to total ownership concentration, most of the top large owners are non-tradable shareholders, such as legal persons and the state with various representatives. For example, the top five shareholders hold 50.57 percent of shares on average, and 90 percent of these shares are non-tradable in our sample period. Firm performance is not a determination for changing the controlling position of large shareholders. Therefore, the liquidity effect functions with respect total ownership concentration in China. Thus we present our fourth hypothesis:

H4: Total ownership concentration is positively related to earnings management due to the liquidity effect resulting from non-tradable ownership.

In contrast, tradable ownership is less concentrated than total ownership. For example, the top five tradable shareholders only hold 14.64 percent tradable shares on average. The large tradable shareholders are confronted with both expropriations by large non-tradable shareholders and entrenchment by managers. Firm performance and resulting trading behaviour not only determines returns, but also changes the firm's position in ownership ranking. Thus, the large tradable shareholders have a great incentive to monitor firms that mitigate their earnings management. The lock-up effect functions with respect to tradable ownership concentration. Thus we present our fifth hypothesis:

H5: Tradable ownership concentration is negatively related to earnings management due to the lock-up effect resulting from tradable ownership. 
Institutional investors are generally thought to have better access to timely information and to be capable of accurate analysis. Thus, institutional investors are more capable of detecting earnings management than individual investors. Also, institutional investors usually hold a larger number of shares than individual investors. On one hand, institutional investors have strong incentives to monitor the firm's performance and relevant management that determine the firm's value. On the other hand, institutional investors have monitoring power, in terms of holding a large proportion of shares.

Chung et al. (2002) give evidence that the presence of large institutional shareholdings prevents managers from increasing or decreasing reported profits towards managers' desired level or range of profits. Bushee (1998) find that institutional investors create less incentives for a firm's management to cut research and development expenditures to attain short-term targets. Jiambalvo (1996) find that absolute discretionary accruals have a negative association with institutional ownership. These evidences are consistent with institutional investors monitoring and constraining the self-serving behaviour of corporate managers.

Koh (2007) classify institutional investors into 'transient' or 'long term' by their investment horizons, and examine the association between institutional investor type and firms' discretionary earnings management strategies in two mutually exclusive settings: firms that do and do not use accruals to meet/beat earnings targets. The results show that long-term institutional investors constrain accruals management in firms that manage earnings to meet/beat earnings target. Transient institutional ownership is systematically associated with aggressive earnings management in firms that manage earnings to meet/beat their earnings benchmarks.

China's institutional investors represented by fund companies are often criticized for their spending resources and doing analyses for choosing firms rather on monitoring firms. They are typical transient investors, because they are more likely to sell their shares of poorly 
performing companies and buy shares of good performing companies. Although, selling shares is also an external discipline on firms' management, it is not as effective as monitoring management behaviour. Thus, we present our sixth hypothesis:

H6: Institutional ownership in China does not play a monitoring role to mitigate earnings management.

Some studies suggest that when managers hold a sufficient proportion of ownership, the agency problem should be mitigated, because larger managerial ownership fosters alignment incentives, and thus opportunistic earnings management are not employed (Gul et al., 2003). Warfield et al. (1995) provide evidence that managerial ownership is negatively related to the magnitude of earnings management. They also show that an inverse relationship between managerial ownership and absolute abnormal accruals becomes moderated in the case of regulated firms.

In contrast, some investigations argue that large managerial ownership may give managers enough power to make decisions that suit their own interests. Barnea and Rubin (2010) have shown that ownership by managers and large blockholders (families for example) reduce corporate incentives of social responsibility. Smith (1976) and Dhaliwal et al. (1982) predict that greater managerial ownership has an entrenchment effect. Managers extrapolate private benefits through manipulating earnings at the cost of other shareholders. Considering the new emerging market, which has weak minority shareholders' protection in China, we assume that the entrenchment effect dominates the alignment effect in relation to managerial ownership and earnings management. Thus our seventh hypothesis is:

H7: Managerial ownership is positively associated with earnings management due to the entrenchment effect, which surmounts the alignment effect. 


\section{Data and Variables}

\subsection{Data}

Our initial sample comprises the firms that issued A shares, or also issued B shares or $\mathrm{H}$ shares, and were listed on either the Shanghai or Shenzhen stock exchanges at least for six consecutive years from 1999 to 2010 . The firms that have incomplete data set or are in the financial industry are eliminated. We also exclude firms classified by the China Securities Regulatory Commission (CSRC) as 'particular treatment' (PT) firms. PT firms are classified as having suffered a loss for three consecutive years and thus have heavy restriction in reporting and share trading imposed on them by CSRC. Most PT firms have suspended business, are planned for merger, or are delisted. However, we include 'special treatment' (ST) firms, which are classified as having experienced negative profit for two consecutive years, but they are still operating similar to normal firms.

Since the calculation of earnings quality measures requires yearly incremental data or prior year's data, or both prior and subsequent years data, and the measures are generated by regression modellings within rolling five-year windows, the number of examinable observations diminish. The maximal sample in use consists of 1,176 firms with 7,937 firmyear observations reported from 2004 to 2010, which is an unbalanced panel data set.

The majority of data are collected from the China Stock Market and Accounting Research Database (CSMAR) created by the GTA Information Technology Company and the University of Hong Kong. The supplementary data come from a series of Shanghai Stock Exchange Statistical Annuals, Shenzhen Stock Exchange Fact Books, and from firms' annual reports available from the firms' homepages. Certain errors have been corrected by checking various data sources. 


\subsection{Variables of Earnings Management}

Earnings consist of cash and accruals. Accruals are the difference between earnings and cash flow, and can be divided into normal and discretionary accruals. One role of accruals is to shift or adjust the recognition of cash flows over time so that the adjusted number better measures firm performance. Earnings that map more closely into cash flows are more desirable, and are thus designated as being of high earnings quality. Earnings management leads to increasing divergence between earnings and cash flow, as well as less predictable, and are thus designated as being of low earnings quality. Dechow and Dichev (2002) develop a measure of accruals quality and argue that the quality of accruals and earnings is negatively related to the magnitude of estimation error in accruals. Our first earnings management variable is accrual quality (AccrualQuality) based on Dechow and Dichev's (2002) model relating to total current accruals to the lagged, current, and future cash flows from operations:

$$
\frac{\text { CCA }_{j, t}}{\text { Asset }_{j, t-1}}=b_{0}+b_{1} \frac{C F O_{j, t-1}}{\text { Asset }_{j, t-1}}+b_{2} \frac{C F O_{j, t}}{\text { Asset }_{j, t-1}}+b_{3} \frac{C F O_{j, t+1}}{\text { Asset }_{j, t-1}}+\mathrm{e}_{j, t}
$$

Where $T C A_{j, t}$ represents the firm $j$ 's total current accruals in year $t$; Asset ${ }_{j, t-1}$ is firm $j$ 's total assets in year $t-1 ; C F O_{j, t}$ is firm $j$ 's cash flow from operations in year $t$.

For each firm-year, we estimate Equation (1) by rolling over a five-year window. The accruals quality is represented by the standard deviation of estimated residual $\sigma\left(\hat{\mathrm{e}}_{\hat{j}, t}\right)$. Large (small) values of $\sigma\left(\hat{\mathrm{e}}_{j, t}\right)$ correspond to lower (higher) accruals quality, and lower (higher) earnings quality, because there is less (more) precision about the mapping of current accrual into current-period, last-period, and next-period cash flows.

Normal accruals are those obligatory expenses or income that has yet to be realized, but are already recorded in the account books according to accounting rules; while discretionary accruals (DisAccrual) describe where the company uses its own discretion (rather than procedural obligations) in deciding whether or not to make the accruals. If they choose not to 
make the accruals, they do not show the liability or revenue on their financial statements. Thus, discretionary accruals are a practical tool in earnings management. Our second earnings management variable is the absolute value of discretionary accruals (AdisAccrual) calculated using the Jones model and the modified Jones model (Dechow et al., 1995)

$$
\begin{aligned}
& \frac{T A_{j, t}}{\text { Asset }_{j, t-1}}=k_{1} \frac{1}{\text { Assets }_{j, t-1}}+k_{2} \frac{\Delta \operatorname{Rev}_{j, t}}{\text { Asset }_{j, t-1}}+k_{3} \frac{P P E_{j, t}}{\text { Asset }_{j, t-1}}+\omega_{j, t} \\
& N D A_{j, t}=\hat{k}_{1} \frac{1}{\text { Assets }_{j, t-1}}+\hat{k}_{2} \frac{\Delta \operatorname{Rev}_{j, t}-\Delta A R_{j, t}}{\text { Asset }_{j, t-1}}+\hat{k}_{3} \frac{P P E_{j, t}}{\text { Asset }_{j, t-1}} \\
& D A_{j, t}=\frac{T A_{j, t}}{\text { Asset }_{j, t-1}}-N D A_{j, t}
\end{aligned}
$$

Where: $T A j, t$ represents the total accruals of firm $j$ in year $t$, which is equal to total current accruals plus depreciation; $\operatorname{Rev} j, t$ is the revenue of firm $j$ in year $t ; P P E j, t$ is the gross property, plant and equipment; $A R j, t$ is the accounting receivable of firm $j$ in year $t ; N D A j, t$ represents nondiscretionary accruals; and $D A j, t$ represents discretionary accruals.

\subsection{Variables of Ownership Characteristics}

The firms listed in China's domestic market might only issue A shares to domestic investors, or also issue $\mathrm{B}$ shares to both foreign and domestic investors, or also issue $\mathrm{H}$ shares in the Hong Kong market for foreign investors. We set a foreign investment dummy (ForeignInv) that codes 1 if a firm issued foreign shares and 0 otherwise. The firms that solely issued $\mathrm{B}$ shares or $\mathrm{H}$ shares are not included in this research.

The largest shareholder of a firm can be the state, a family founder, a collective entity, or a legal person. We set a state dummy (StateLargest) that codes 1 if a state agency is the largest owner and 0 otherwise. The largest shareholders are most likely the controlling shareholders in the context of China.

The state ownership ratio (StateRatio) is calculated as the number of shares held by the state divided by the total number of shares outstanding. The state can be represented by 
various state agencies, such as State Asset Management Bureaus, SOEs affiliated to the central government, and SOEs affiliated to local government. Alternatively the state can be represented by different entities.

The tradable share ratio (TradeRatio) is calculated as the number of tradable shares divided by total number of shares outstanding. The tradable shares consist of tradable A shares, B shares, and $\mathrm{H}$ shares.

The total ownership concentration (Top5Total) is measured as a ratio of the number of shares held by the top five large shareholders divided by total number of shares outstanding. In most firms, the top five large shareholders comprise mainly non-tradable shareholders.

The tradable ownership concentration (Top5Ttrade) is measured as a ratio of the number of shares held by the top five tradable shareholders divided by total number of tradable shares outstanding. Tradable shares are exclusive in this measure.

Institutional ownership by fund companies (FundRatio) is measured as a ratio of the number of shares held by fund companies divided by the total number of shares. Because the institutional shareholders have unclear definitions in China's market, the fund ratio is a better proxy of institutional ownership and embodies a more sensible analysis.

Managerial ownership (ManagRatio) is measured as a ratio of the number of managerial shares divided by total number of shares outstanding. In CSMAR data, there are two categories of managerial shares. The broad one refers shares held by total members in director, supervisor, and top management teams. The narrowed one, which we selected for this research, refers only to the shares held by members of the top management team.

\subsection{Control Variables}

We consider the several control variables of firm characteristics in our regression analyses. Firm size is a logarithm of total assets (LogAsset). Leverage (Leverage) is the ratio of total liability to total assets. Growth is the increase in the ratio of annual sale (GrowthSale). 
Financial distress (FirmST) is a dummy variable that codes 1 if a firm is designated by CSRC as ST firm and 0 otherwise. We also included an industry dummy variable (IndustryD) to control for the difference in accruals properties across industries, and a yearly dummy (YearD) variable to control for the possible policy change in the sample period.

In order to avoid the influence of extreme outliners, we follow the practice suggested by Francis et al. (2004) that involves winsorizing the values of accruals quality, discretionary accruals, absolute value of discretionary accruals, leverage and growth in sale the 99 and 1 percents.

\section{Descriptive statistics}

Panel A of Table 1 presents the statistics of earnings management measures. As Cornett (2008) indicates, discretionary accruals must be revised at some point. The average value should be near zero, due to the summation of positive and negative discretionary accruals generated from auto-regression. The mean and median of discretionary accruals in our sample are small, at 0.51 percent and -0.01 percent of assets. The mean and median of the absolute value of discretionary accruals are relatively large, at 6.76 percent and 3.60 percent of assets. The mean and median of accruals quality are at 4.18 percent and 2.66 percent of assets. Both discretionary accruals and accruals quality have larger means than medians. This implies that the values of earnings management measures are right skewed, and thus some firms manage earnings seriously than majority firms do.

\section{< Table 1 here $>$}

Panel B of Table 1 summarizes the statistics of ownership characteristics. According to our calculations, 9.81 percent of firms issued B shares or/and $\mathrm{H}$ shares, and simultaneously has A shares listed on the market. Approximately 90 percent of firms are exclusively owned by domestic investors. The state (a state representative or entity) is the largest shareholder in 
50.98 percent of listed firms, which indicates that the state took important role in controlling listed companies. However, the state share ratio is 22.73 percent, which is relatively lower than the 50.98 percent of firms in which state is the largest shareholder. One reason is that this 22.73 percent is an equal weighted average; if the value weighted average is applied it would reach 36.19 percent. The other cause is that the CSRC promulgated a provision in 2005 to eliminate non-tradable shares. ${ }^{1}$ Many state-controlled firms reduced their nondurable shares to a threshold of ownership are still large enough to control the firms in this period.

The tradable shares are accounted for 61.38 percent of total shares outstanding on average. Tradable ownership increases over recent years, and firms with full tradable ownership emerge. The total ownership is highly concentrated. Approximately 50.57 percent of shares, on average, are owned by the top five large shareholders, which means that they are able to control at least half of the stock market. The tradable ownership concentration is relatively low. The top five tradable share investors hold 14.64 percent of tradable shares. However, they have leverage effect in determining market prices, because approximately 40 percent of shares are non-tradable. The institutional ownership by fund companies and managerial ownership is quite low, with values of only 2.95 and 0.1 percent respectively. Many firms have never allocated shares to managers and/or have no investors of fund companies, although we believe this situation will change.

Panel C of Table 1 describes firms' characteristics that are control variables in our regression analyses. The average size of listed firms is 5,700 million Chinese yuan, which is larger than the values of median, 25th and 75th percentiles, and thus shows that most firms are small in size. The leverage is 57.23 percent on average, indicating that more than half of capital is made up of liabilities for most firms. The annual growth of sales is high, at 19.03 percent on average, although at least 25 percent of firms have negative growth ratios. 
The correlation coefficients between variables in regression analyses are arranged in Table 2. The upper triangular matrix represents a Spearman correlation and the lower triangular matrix represents a Pearson correlation. Values in italics are probabilities of significances. Overall, the signs and values of most coefficients in the corresponding cells of the two matrixes have no meaningful differences. Asymmetric distribution of variables seem not serious to produce biased results. To save space, we refer to the Pearson correlation in the lower triangular matrix in the following discussion.

\section{$<$ Table 2 here $>$}

From Table 2, we may observe that the earnings management variables of discretionary accruals and accruals quality are negatively correlated with the state largest ownership dummy, tradable ownership ratio, tradable ownership concentration and institutional ownership ratio; and are positively correlated with the foreign investment dummy, state ownership ratio, total ownership concentration and managerial ownership ratio. The signs of those correlation coefficients are consistent with our hypotheses except for concerning statistical significance. A correlation coefficient represents a naïve relationship between the two variables, which does not consider the influence of other variables that must be controlled against each other. Thus, with reference to the correlation coefficients, we herewith conduct regression analyses.

\section{Regression Analyses}

\subsection{Regression with Individual Ownership Variable}

We first regress on earnings management with individual ownership characteristics and control variables. The results with the dependent variable of absolute discretionary accruals are arranged in Panel A of Table 3, and the results with the dependent variable of accrual quality are arranged in Panel B of Table 3. 
The coefficients of ForeignInv are positive and statistically significant at the five percent level in Panel B, where the dependent variable is accrual quality. They are the evidence that foreign ownership and foreign accounting standards cannot monitor firms to reduce earnings management. Instead, the coexistence of domestic and foreign ownership in a firm may encourage the manager to manipulate earnings in preparation of financial reports, so that it complies with both domestic and international accounting standards. Thus, the regressions results regarding foreign ownership in our study convince the first hypothesis that firms with foreign investment in $\mathrm{B}$ shares or $\mathrm{H}$ shares may have more incentives to manage earnings than firms only with domestic investment in A shares. Our result is likely consistent with that of Wang and Campbell (2012) who state that the application of IFRS does not deter earnings management. However, our results are against that of $\mathrm{Xu}$ et al. (2012) and Firth et al. (2007). Xu et al. (2012) show that firms controlled by foreign investors have higher earnings quality than firms controlled by state. Firth et al. (2007) indicate that foreign shareholders appear to enhance the earnings-returns relation.

\section{$<$ Table 3 here $>$}

The state ownership ratio (StateRatio) has a positive coefficient, but is statistically insignificant; while the state dummy (StateLargest) has a negative coefficient and is significant at one percent level in both Panel A and Panel B. State ownership seems not a determinant on earnings management. However, when a state agency is the largest owner, firms are most likely in key industries and have more ways to access capital and resources. The managers are also possibly assigned by state authorities and compensated by both remuneration and political promotion. Earnings management therefore is less meaningful. The result is consistent with our second hypothesis: State ownership is positively related to earnings management unless a state agency is the largest shareholder of the firm, in which earnings management incentives and necessity are mitigated. Our finding is somehow close 
to that of Wang and Yung (2011), who claim that the level of earnings management of stateowned enterprises is lower than that of privately-owned firms in China even after controlling for the effect of tunneling. But our results counter that of Xu et al. (2012). They argue that firms controlled by foreign investors have higher earnings quality than firms controlled by state.

The coefficients of tradable share ratio (TradeRatio) are negative at the one percent significant level. In comparison with non-tradable shareholders, tradable shareholders have dual ways to monitor managers. While tradable shareholders have voting rights to directly intervene in managers' decisions, they are also subdued by an external discipline force that occurs when selling shares to indirectly influence managers' decisions. Managers pay more attention to tradable shareholders' responses when they make decisions that are not aligned with shareholder interests. The results support our third hypothesis, that the tradable ownership ratio is negatively associated with earnings management due to the disciplining power from selling shares. Firth et al. (2007) also show that the percentage of tradable shares appear to enhance the earnings-returns relation that is an evidence of high earnings quality and low earnings management.

The total ownership concentration (Top5Total) has positive coefficients, and these are significant at the one percent level in both Panels A and B. This result coincides with the evidence in Haw et al. (2004) and Leuz (2006). Highly concentrated ownership provides large shareholders with sufficient power to direct managers into taking actions to expropriate minority shareholders' wealth, while minority shareholders have a free ride in monitoring managerial decisions. Thus, the results support our fourth hypothesis, that total ownership concentration is positively related to earnings management due to the liquidity effect resulting from large non-tradable ownership. In this definition of ownership concentration, our result seems not to be against previous evidences. Firth et al., 2007 indicate that firms 
with highly concentrated share ownership have lower earnings informativeness. Liu and Lu (2007) document that the ownership of top one shareholder has positive relation while the ownership of top 2 to top 10 shareholders has negative relation with earnings management.

Contrary to the situation for Top5Total, the Top5Trade has negative coefficients: one is at one percent significance in Panel A and the other is at 10 percent significance in Panel B. The ownership of large tradable shareholders is most likely smaller than that of large nontradable shareholders, and thus large tradable shareholders have no controlling power to expropriate other shareholders' wealth. Instead, they are confronted with tunnelling from controlling shareholders and entrenchment from managers. Their ownership stake has sufficient worth for them to monitor the firms' operation. Thus, the results confirm our fifth hypothesis, that tradable ownership concentration is negatively related to earnings management due to the lock-up effect resulting from tradable ownership.

The coefficients of institutional ownership by fund companies (FundRatio) are statistically insignificant, although they have a negative sign in Panel A and a positive sign in Panel B. China's institutional investors represented by fund companies are transient, rather than long-term investors. They are more likely to move investment from underperforming firms, and be unwilling to spend resources on monitoring firms. This coincides with our sixth hypothesis, that institutional ownership in China cannot play a monitoring role in monitoring earnings management in China. Our result support Firth et al. (2007)'s argument that institutional ownership are not likely to influence accounting quality in China.

Managerial ownership (ManagRatio) has positive coefficients that are insignificant on the dependent variable of AdisAccrual and significant at the one percent level on the dependent variable of AccrualQuality. In China, managerial ownership is only approximately 0.1 percent on average, which is too low to align managers' interests with shareholders' benefits. Instead, the managers who own the shares in firms expect compensation from both 
salary and ownership, which may be approached by earnings management. The seventh hypothesis is therefore confirmed: managerial ownership is positively associated with earnings management due to the entrenchment effect, which surmounts the alignment effect. Our result refutes Liu and Yung (2011)'s evidence that managerial ownership is most likely reduce earnings management.

The regression performed also generates highly consistent coefficients with each control variable on two dependent variables. The coefficients of control variables are also meaningfully in line with the literature. Previous studies have predicted (and found) that firm size is negatively associated with earnings management because fixed costs are associated with maintaining adequate internal control procedures over financial reporting (Ball and Foster, 1982). Small firms are more likely to have internal control deficiencies, and thus correct previously reported earnings (Kinney and McDaniel, 1989; Ge and McVay, 2005).

Watts and Zimmerman (1986) argue that a high leverage may imply that a firm is closer to a debt covenant restriction. Thus, managers of highly leveraged firms could take action to boost income and manipulate financial reporting so as to avoid violating debt covenants. Dechow et al. (1996) find that earnings manipulation firms have higher leverage ratios and are more likely to have approached violation of debt covenants during and after the manipulation period than normally leverage firms.

Many researchers have investigated the relationships between firms' growth and earnings quality in different dimensions. They have found that high-growth firms have lower earnings quality represented by earnings persistence; in particular, when growth is measured using sales growth or net operating asset growth (Nissim and Penman, 2001; Penman and Zhang, 2002). Low earnings quality could be the result of measurement errors in earnings and earnings management opportunities (Richardson et al., 2005). Firms manipulate earnings by changing product prices or offering credit sales. 
Firm performance can be causally connected with earnings management. On one hand, earnings management may mislead investors, and firms' decisions made based on the mendacious information could distort firms' operation. On the other hand, weak performance provides managers with incentives to engage in earnings management. Firms that perform poorly are more likely to engage in earnings-increase management to avoid financial distress and bankruptcy (Doyle et al., 2007a; Kinney and McDaniel, 1989).

\subsection{Regression with Various Ownership Variables}

The prior regression analyses on earnings management with individual ownership characteristics may ignore the co-effect of various ownership characteristics on earnings management. Here, we regress on earnings management with various ownership characteristics simultaneously. As observed in Table 2, the correlation coefficients between StateRatio and StateLargest, between TradeRatio and StateRatio, and between Top5Total and Top5Trade are larger than 55 percent, multicorrllinearity may exist. Thus, we structured two regression models with ownership variables that do not incur multicorrllinearity and arrange the results in Table 4.

\section{< Table 4 here $>$}

The results of Model 9 and Model 10 in Table 4 match well with those in Panel A of Table 3, and the results of Model 11 and Model 12 are very similar to those in Panel B of Table 3. The signs and significances of the variable coefficients of Models 9-12 in Table 4 almost replicate those of Models 1-8 in Table 3, although the magnitudes and $t$-statistics of coefficients have changed somewhat. The evidences with co-effects of various ownership characteristics nevertheless support our hypotheses.

\subsection{Robustness Tests}

Endogeneity is a problem that may introduce estimation bias. However, the variables of ownership characteristics are not endogenous with variables in the regression models. 
Ownership characteristics are pre-determined by firms' financing strategies, CSRC official listing rules, and ongoing reform policies. For example, the proportions of tradable ownership, non-tradable ownership, and foreign ownership were decided by the firms in terms of firms' preference and listing rules, and were approved by the CSRC. The ownership structure would not change unless that new ownership policy is promulgated.

In contrast, the firm's characteristics variables, such as firm size and leverage ratio may be determined by firm growth and industry categories. Although firm size and leverage ratio are control variables, incorrect specification will alter the regression results. Thus, we identify LogAsset and Leverage as endogenous variables, and selected GrowthSale, EBIT (earnings before interest and tax) and the set of independent variables in the original models as instruments. The two-stage regression (2SLS) results with Models 13-16 are reported in Table 5.

We compared the results generated by OLS and 2SLS with the dependent variables AdisAccrual and AccrualQuality respectively. We find that the coefficients are quite consistent in signs and statistical significance between Models 9 and 13, 10 and 14, 11 and 15, and 12 and 16. Thus, endogeneity is not a problem in our regression modelling.

\section{$<$ Table 5 here $>$}

\section{Conclusions}

Our research, using a relatively recent sample of Chinese listed firms from 2004 to 2010, intensively investigates the impact of ownership characteristics on earnings management behaviour, including foreign ownership, state ownership, tradable ownership, institution ownership, managerial ownership. In particular, we define two types of ownership concentration: total ownership concentration and tradable ownership concentration. We suspect that the tradable ownership concentration has different determination from total 
ownership concentration on earnings management. We also offer some insight into the determinants of the most important ownership characteristics on earnings management.

Our research shows that firms with both domestic and foreign ownership conduct more earnings management, because they are more likely to force their financial reports to comply with both domestic and international accounting standards. We show that state ownership is positively related to earnings management, because of the existence of several state representatives or state share owners in a firm. However, when a state representative or entity is the largest shareholder, earnings management lacks incentives, because the firm has an advantage in access to resources and market.

Total ownership concentration coexists with earnings management. Controlling shareholders expropriate free-riding minority shareholders' wealth to force managers to report earnings on their own interests. However, large tradable shareholders have no controlling power in most firms, because they are measurably inferior to large non-tradable shareholders in terms of ownership. Tradeable ownership resists earnings management, because the selling of shares is a disciplinary tool on managers' behaviours. Thus tradable ownership concentration is negatively associated with earnings management.

Institutional investors, represented by fund companies, prefer moving investments from underperforming firms to performing firms, rather than effective monitoring firm management. Thus, institutional ownership has an insignificant relationship with earnings management. Managerial ownership emerges recent years, but it is quite low for China's firms. However, it appears to be positively associated with earnings management due to the entrenchment effect, which surmounts the alignment effect.

The China's publicly listed firms are charactered with multiple ownerships. Each type of shareholders has their own incentives in the earnings management of firms. The incentives and the resulted earning management are ultimately derived by their expectation on the 
interest and benefit that could be obtained from the earnings management.

\section{Notes}

1. In August 2005 the CRSC issued a guideline for publicly listed firms to reduce nontradable ownership. The firms were able to sell part of their non-tradable shares agreed by the CRSC to institutional investors. The non-tradable shares' buyers were not allowed to trade purchased shares in a lock-up period of one to two years (Jinggu and $\mathrm{Ri}, 2006)$.

\section{References}

Ball, R. and G. Foster (1982), 'Corporate Financial Reporting: A Methodological Review of 
Empirical Research', Journal of Accounting Research,Vol.20, pp. 161-234.

Barnea, A. and A. Rubin (2010), 'Corporate Social Responsibility as a Conflict between Shareholders', Journal of Business Ethics, Vol.97, No.1, pp. 71-86.

Beaver, W., M. McNichols and K. Nelson (2007), 'An Alternative Interpretation of the Discontinuity in Earnings Distributions', Review of Accounting Studies, Vol.12, No.4, pp. $525-56$.

Bushee, B. J. (1998), 'The Influence of Institutional Investors on Myopic R\&D Investment Behaviour', Accounting Review, Vol.73, No.3, pp. 267-92.

Chen, X., C. Lee and J. Li (2008), 'Government Assisted Earnings Management in China', Journal of Accounting and Public Policy, Vol.27, No.3, pp. 262-74.

Chung, R., M. Firth and J. Kim (2002), 'Institutional Monitoring and Opportunistic Earnings Management', Journal of Corporate Finance, Vol.8, No.1, pp. 29-48.

Dechow, P. and I. Dichev (2002), 'The Quality of Accruals and Earnings: The Role of Accruals Estimation Errors', Accounting Review, Vol.77, No.S-1, pp. 35-59.

Dechow, P., S. Richardson and I. Tuna (2003), 'Why are Earnings Kinky? An Examination of the Earnings Management Explanation', Review of Accounting Studies, Vol.8, Nos.2\&3, pp. 355-84.

Dechow, P., R. Sloan and A. Sweeney (1996), 'Causes and Consequences of Earnings Manipulation: An Analysis of Firms subject to Enforcement Actions by the SEC', Contemporary Accounting Research, Vol.13, No.1, pp. 1-36.

Dhaliwal, D., G. Salamon and E. Smith (1982), 'The Effect of Owner versus Management Control on the Choice of Accounting Methods', Journal of Accounting and Economics, Vol. 4, No.1, pp. 41-53.

Ding, Y., H. Zhang and J. Zhang (2007), 'Private vs. State Ownership and Earnings Management: Evidence from Chinese Listed Companies', Corporate Governance: An 
International Review, Vol.15, No.2, pp. 223-38.

Doyle, J., W. Ge and S. McVay (2007a), 'Accruals Quality and Internal Control over Financial Reporting', Accounting Review, Vol.82, No.5, pp. 1141-70.

Doyle, J., W. Ge, and S. McVay (2007b), 'Determinants of Weaknesses in Internal Control over Financial Reporting', Journal of Accounting and Economics, Vol.44, No.1, pp. 193223.

Easley, D. and M. O'Hara (2004), 'Information and the Cost of Capital', Journal of Finance, Vol.59, No.4, pp. 1553-83.

Farber, D. B. (2005), 'Restoring Trust After Fraud: Does Corporate Governance Matter?', Accounting Review, Vol.80, No.2, pp. 539-61.

Firth, M., P. M. Y. Fung and O. M. Rui (2007), 'Ownership, Two-tier Board Structure, and the Informativeness of Earnings -Evidence from China', Journal of Accounting and Public Policy, Vol.26, No.4, pp. 463-96.

Francis, J., R. LaFond, P. Olsson and K. Schipper (2004), 'Costs of Equity and Earnings Attributes', Accounting Review, Vol.79, No.4, pp. 967-1010.

Ge, W. and S. McVay (2005), 'The Disclosure of Material Weaknesses in Internal Control after the Sarbanes-Oxley Act', Accounting Horizons, Vol.19, No.3, pp. 137-58.

Gedajlovic, E., T. Yoshikawa and M. Hashimoto (2005), 'Ownership Structure, Investment Behaviour and Firm Performance in Japanese Manufacturing Industries', Organization Studies, Vol.26, No.1, pp. 7-35.

Gul, F., C. Chen and J. Tsui (2003), 'Discretionary Accounting Accruals, Managers' Incentives, and Audit Fees', Contemporary Accounting Research, Vol.20, No.3, pp. 44164.

Gul, F., J. Kim and A. Qiu (2010), 'Ownership Concentration, Foreign Shareholding, Audit Quality, and Stock Price Synchronicity: Evidence from China', Journal of Financial 
Economics, Vol.95, No.3, pp. 425-42.

Gunasekarage, A., K. Hess and A. Hu (2007), 'The Influence of the Degree of State Ownership and the Ownership Concentration on the Performance of Listed Chinese Companies', Research in International Business and Finance, Vol.21, No.3, pp. 379-75.

Haw, I., B. Hu, L. Hwang and W. Wu (2004), 'Ultimate Ownership, Income Management, and Legal and Extra-legal Institutions', Journal of Accounting Research, Vol.42, No.2, pp. 423-462.

Hayn, C. (1995), 'The Information Content of Losses', Journal of Accounting and Economics, Vol.20, No.2, pp. 125-53.

Heugens, P. M. A. R., M. V. Essen and J. V. Oosterhout (2009), 'Meta-analyzing Ownership Concentration and Firm Performance in Asia: Towards a more Fine-grained Understanding', Asia Pacific Journal of Management, Vol.26, No.3, pp. 481-512.

Jiambalvo, J. (1996), 'Discussion of Causes and Consequences of Earnings Manipulation: An Analysis of Firms subject to Enforcement Actions by the SEC', Contemporary Accounting Research, Vol.13, No. 1, pp. 37-47.

Jingu, T. and S. Ri (2006), 'Reforms to Chinese Non-tradable Shares', Nomura Securities Economic Research 11 April.

Jiraporn, P. and K. C. Gleason (2007), 'Delaware Incorporation and Earnings Management: An Empirical Analysis', Journal of Applied Finance, Vol.17 (Spring/Summer), pp. 405161.

Joe, J. and S. Vandervelde (2007), 'Do Auditor-provided Nonaudit Services Improve Audit Effectiveness?', Contemporary Accounting Research, Vol.24, No.2, pp. 467-87.

Kinney, W. and L, McDaniel (1989), 'Characteristics of Firms Correcting previously Reported Quarterly Earnings', Journal of Accounting and Economics, Vol.11, No.1. pp. 71-93. 
Koh, P. S. (2007), 'Institutional Investor Type, Earnings Management and Benchmark Beaters', Journal of Accounting and Public Policy, Vol.26, No.3, pp. 267-99.

Leuz, C. (2006), 'Cross Listing, Bonding and Firms' Reporting Incentives: A Discussion of Lang, Raedy and Wilson', Journal of Accounting and Economics, Vol.42, No.1, pp. 28599.

Leuz, C., D. Nanda and P. Wysocki (2003), 'Earnings Management and Investor Protection: An International Comparison', Journal of Financial Economics, Vol.69, No.3, pp.505-27. Liu, Q. and Z. Lu (2007), 'Corporate Governance and Earnings Management in the Chinese Listed Companies: A Tunneling Perspective', Journal of Corporate Finance, Vol.13, No. 5, pp. 881-906.

Ma, S., T. Naughton and G. Tian (2010), 'Ownership and Ownership Concentration: Which is Important in Determining the Performance of China's Listed Firms?', Accounting and Finance, Vol.50, No.4, pp. 871-97.

Maug, E. (1998), 'Large Shareholders as Monitors: Is there a Trade-off between Liquidity and Control?', Journal of Finance, Vol.53, No.1. pp. 65-98.

Maydew, E. (1997), 'Tax-induced Earnings Management by Firms with Net Operating Losses', Journal of Accounting Research, Vol.35, No.1, pp. 83-96.

Nissim, D. and S. Penman (2001), 'Ratio Analysis and Equity Valuation: from Research to Practice', Review of Accounting Studies, Vol.6, No.1, pp. 109-54.

Penman, S. and X. Zhang (2002), 'Accounting Conservatism, the Quality of Earnings, and Stock Returns', Accounting Review, Vol. 77, No.2, pp. 237-64.

Pincus, M., S. Rajgopal and M. Venkatachalam (2007), 'The Accrual Anomaly: International Evidence, Accounting Review, Vol.82, No.1, pp. 169-203.

Richardson, S., R. Sloan, M. Soliman and I. Tuna (2005), 'Accrual Reliability, Earnings Persistence and Stock Prices', Journal of Accounting and Economics, Vol.39, No.3, pp. 
$437-85$.

Scholes, M., G. Wilson and M. Wolfson (1992), 'Firms' Responses to Anticipated Reductions in Tax Rates: The Tax Reform Act of 1986', Journal of Accounting Research, Vol.30, No.s, pp. 161-85.

Smith, E. (1976), 'The Effect of the Separation of Ownership from Control on Accounting Policy Decisions', Accounting Review, Vol.51, No.4, pp. 707-23.

Sun, Q., H. Wilson, S. Tong and J. Tong (2002), 'How Does Government Ownership Affect Firm Performance? Evidence from China's Privatization Experience', Journal of Business Finance \& Accounting, Vol.29, Nos.1\&2, pp. 1-27.

Wang, L. and K. Yung (2011), 'Do State Enterprises Manage Earnings More than Privately Owned Firms? The Case of China', Journal of Business Finance \& Accounting, Vol.38, Nos.7\&8, pp. 794-812.

Wang, Y. and M. Campbell (2012), 'Corporate Governance, Earnings Management, and IFRS: Empirical Evidence from Chinese domestically Listed Companies', Advances in Accounting, Vol.28, No.1, pp. 189-92.

Xu, W., K. Wang and A. Anandarajan (2012), 'Quality of Reported Earnings by Chinese Firms: The Influence of Ownership Structure', Advances in Accounting, Vol.28, No.1, pp. 193-99. 
Table 1. Summary statistics of earnings management, ownership characteristics and firm characteristics

AccrualQuality is accrual quality, DisAccruals is discretionary accruals, AdisAccruals is absolute value of discretionary accruals, ForeignInv is foreign investment dummy that codes 1 if a firm issued foreign shares and 0 otherwise, StateLargest is state control dummy that codes 1 if the state is the largest owner and 0 otherwise, StateRatio is state ownership ratio, TradeRatio is tradable share ratio. Top5Total is total ownership concentration, Top5Ttrade tradable ownership concentration, FundRatio is institutional ownership ratio, ManagRatio is managerial ownership ratio, Assets are total assets, Leverage is the ratio of liability to assets, GrowthSale is the growth ratio of annual sales, FrimST is a dummy variable that codes 1 if a firm is designated by CSRC as ST firm and 0 otherwise.

\begin{tabular}{|c|c|c|c|c|c|c|c|}
\hline Variable definition & Mean & $\begin{array}{r}\text { Standard } \\
\text { deviation }\end{array}$ & $\begin{array}{c}\text { 10th } \\
\text { percentile }\end{array}$ & $\begin{array}{c}25 \text { th } \\
\text { percentile }\end{array}$ & Median & $\begin{array}{c}\text { 75th } \\
\text { percentile }\end{array}$ & $\begin{array}{c}\text { 90th } \\
\text { percentile }\end{array}$ \\
\hline
\end{tabular}

\begin{tabular}{|c|c|c|c|c|c|c|c|}
\hline \multicolumn{8}{|c|}{ Panel A: Earnings management } \\
\hline AccrualQuality & 0.0418 & 0.0522 & 0.0046 & 0.0117 & 0.0266 & 0.0532 & 0.0920 \\
\hline DisAccruals & 0.0051 & 0.4032 & -0.0944 & -0.0361 & -0.0001 & 0.0359 & 0.0970 \\
\hline AdisAccruals & 0.0676 & 0.0983 & 0.0049 & 0.0141 & 0.0360 & $0 . .0861$ & 0.1522 \\
\hline \multicolumn{8}{|c|}{ Panel B: Ownership characteristics } \\
\hline ForeignInv (dummy) & 0.0981 & 0.2975 & 0 & 0 & 0 & 0 & 0 \\
\hline StateLargest (dummy) & 0.5098 & 0.4999 & 0 & 0 & 1.0000 & 1.0000 & 1.0000 \\
\hline StateRatio (\%) & 22.73 & 23.67 & 0 & 0 & 16.39 & 42.95 & 57.34 \\
\hline TradeRatio (\%) & 61.38 & 23.59 & 33.00 & 42.70 & 57.12 & 79.99 & 100.00 \\
\hline Top5Total (\%) & 50.57 & 15.23 & 30.35 & 39.62 & 50.94 & 61.20 & 67.74 \\
\hline Top5Ttrade (\%) & 14.64 & 17.50 & 0.95 & 2.15 & 7.06 & 20.16 & 43.76 \\
\hline FundRatio (\%) & 2.95 & 6.78 & 0 & 0 & 0.01 & 1.99 & 10.48 \\
\hline FundRatio (\%) & 5.22 & 5.34 & 0.010 & 0.04 & 1.28 & 6.91 & 16.42 \\
\hline ManagRatio (\%) & 0.10 & 1.35 & 0 & 0 & 0 & 0 & 0.02 \\
\hline ManagRatio (\%) & 0.44 & 2.77 & 0 & 0 & 0.002 & 0.04 & 0.144 \\
\hline \multicolumn{8}{|l|}{ Panel C: Firm characteristics } \\
\hline Assets (million) & 5706 & 24599 & 529 & 1008 & 2097 & 4476 & 9972 \\
\hline Leverage (Liability/assets) & 0.5723 & 0.3032 & 0.2712 & 0.4024 & 0.5463 & 0.6759 & 0.8033 \\
\hline GrowthSale & 0.1903 & 0.5044 & -0.2499 & -0.0367 & 0.1278 & 0.3133 & 0.5906 \\
\hline FrimST (dummy) & 0.1348 & 0.3415 & 0 & 0 & 0 & 0 & 1.0000 \\
\hline
\end{tabular}

*All means are equal weighted averages. The value weighted average of state ownership is $36.19 \%$. 
Table 2. Correlation coefficients between any pair variables of earnings management, ownership and firm characteristics

AccrualQuality is accrual quality, DisAccruals is discretionary accruals, AdisAccruals is absolute value of discretionary accruals, ForeignInv is foreign investment dummy that codes 1 if a firm issued foreign shares and 0 otherwise, StateLargest is state control dummy that codes 1 if the state is the largest owner and 0 otherwise, StateRatio is state ownership ratio, TradeRatio is tradable share ratio. Top5Total is total ownership concentration, Top5Ttrade tradable ownership concentration, FundRatio is institutional ownership ratio, ManagRatio is managerial ownership ratio, LogAsset is logarithm of total assets, Leverage is the ratio of liability to assets, GrowthSale is the growth ratio of annual sales, FrimST is a dummy variable that codes 1 if a firm is designated by CSRC as ST firm and 0 otherwise.

\begin{tabular}{|c|c|c|c|c|c|c|c|c|c|c|c|c|c|c|c|}
\hline & & (1) & $(2)$ & (3) & (4) & (5) & (6) & (7) & $(8)$ & (9) & (10) & (11) & (12) & (13) & (14) \\
\hline \multirow[t]{2}{*}{ AdisAccrual } & (1) & 1 & 0.276 & 0.047 & -0.078 & 0.034 & -0.085 & 0.009 & -0.096 & -0.073 & -0.028 & -0.112 & 0.127 & 0.031 & 0.108 \\
\hline & & & $<0.001$ & 0.199 & $<0.001$ & 0.083 & $<0.001$ & 0.41 & $<0.001$ & $<0.001$ & 0.012 & $<0.001$ & $<0.001$ & 0.006 & $<0.001$ \\
\hline \multirow[t]{2}{*}{ AccrualQuality } & (2) & 0.38 & 1 & 0.016 & -0.111 & 0.061 & -0.068 & 0.004 & -0.085 & -0.104 & -0.019 & -0.136 & 0.15 & 0.018 & 0.148 \\
\hline & & $<0.001$ & & 0.192 & $<0.001$ & 0.312 & $<0.001$ & 0.76 & $<0.001$ & $<0.001$ & 0.127 & $<0.001$ & $<0.001$ & 0.152 & $<0.001$ \\
\hline \multirow[t]{2}{*}{ ForeignInv } & (3) & 0.029 & 0.009 & 1 & 0.039 & 0.054 & 0.025 & 0.078 & 0.121 & 0.001 & 0.031 & 0.168 & -0.002 & -0.031 & 0.009 \\
\hline & & 0.212 & 0.495 & & 0 & $<0.001$ & 0.024 & $<0.001$ & $<0.001$ & 0.997 & 0.006 & $<0.001$ & 0.846 & 0.006 & 0.406 \\
\hline \multirow[t]{2}{*}{ StateLargest } & (4) & -0.083 & -0.122 & 0.039 & 1 & 0.8 & -0.367 & 0.213 & -0.289 & 0.108 & 0.016 & 0.175 & -0.107 & 0.031 & -0.123 \\
\hline & & $<0.001$ & $<0.001$ & $<0.001$ & & $<0.001$ & $<0.001$ & $<0.001$ & $<0.001$ & $<0.001$ & 0.162 & $<0.001$ & $<0.001$ & 0.005 & $<0.001$ \\
\hline \multirow[t]{2}{*}{ StateRatio } & $(5)$ & 0.033 & 0.096 & 0.048 & 0.774 & 1 & -0.595 & 0.426 & -0.418 & -0.072 & -0.019 & 0.162 & -0.099 & 0.056 & -0.088 \\
\hline & & 0.165 & 0.222 & $<0.001$ & $<0.001$ & & $<0.001$ & $<0.001$ & $<0.001$ & $<0.001$ & 0.09 & $<0.001$ & $<0.001$ & $<0.001$ & $<0.001$ \\
\hline \multirow[t]{2}{*}{ TradeRatio } & (6) & -0.113 & -0.064 & 0.02 & -0.398 & -0.608 & 1 & -0.623 & 0.725 & 0.001 & 0.053 & 0.089 & -0.048 & -0.074 & -0.073 \\
\hline & & $<0.001$ & $<0.001$ & 0.076 & $<0.001$ & $<0.001$ & & $<0.001$ & $<0.001$ & 0.923 & $<0.001$ & $<0.001$ & $<0.001$ & $<0.001$ & $<0.001$ \\
\hline \multirow[t]{2}{*}{ Top5Total } & (7) & 0.027 & 0.013 & 0.109 & 0.211 & 0.466 & -0.572 & 1 & -0.113 & -0.097 & -0.11 & 0.21 & -0.086 & 0.124 & -0.071 \\
\hline & & 0.016 & 0.315 & $<0.001$ & $<0.001$ & $<0.001$ & $<0.001$ & & $<0.001$ & $<0.001$ & $<0.001$ & $<0.001$ & $<0.001$ & $<0.001$ & $<0.001$ \\
\hline \multirow[t]{2}{*}{ Top5Ttrade } & (8) & -0.096 & -0.063 & 0.118 & -0.36 & -0.422 & 0.748 & -0.062 & 1 & 0.149 & 0.014 & 0.24 & -0.089 & 0.009 & -0.12 \\
\hline & & $<0.001$ & $<0.001$ & $<0.001$ & $<0.001$ & $<0.001$ & $<0.001$ & $<0.001$ & & 0.207 & $<0.001$ & $<0.001$ & $<0.001$ & 0.428 & $<0.001$ \\
\hline \multirow[t]{2}{*}{ FundRatio } & (9) & -0.057 & -0.055 & -0.013 & 0.033 & -0.032 & 0.12 & -0.009 & 0.149 & 1 & 0.207 & 0.277 & -0.078 & 0.088 & -0.155 \\
\hline & & $<0.001$ & $<0.001$ & 0.242 & 0.003 & 0.005 & $<0.001$ & 0.401 & $<0.001$ & & $<0.001$ & $<0.001$ & $<0.001$ & $<0.001$ & $<0.001$ \\
\hline \multirow[t]{2}{*}{ ManagRatio } & (10) & 0.005 & 0.033 & -0.02 & -0.07 & -0.066 & 0.034 & -0.007 & 0.046 & 0.081 & 1 & 0.007 & -0.03 & -0.002 & -0.028 \\
\hline & & 0.683 & 0.008 & 0.073 & $<0.001$ & $<0.001$ & 0.003 & 0.512 & $<0.001$ & $<0.001$ & & 0.529 & 0.008 & 0.843 & 0.012 \\
\hline \multirow[t]{2}{*}{ LogAsset } & (11) & -0.176 & -0.234 & 0.142 & 0.164 & 0.128 & 0.096 & 0.156 & 0.261 & 0.405 & 0.024 & 1 & -0.077 & 0.221 & -0.325 \\
\hline & & $<0.001$ & $<0.001$ & $<0.001$ & $<0.001$ & $<0.001$ & $<0.001$ & $<0.001$ & $<0.001$ & $<0.001$ & 0.033 & & $<0.001$ & $<0.001$ & $<0.001$ \\
\hline Leverage & (12) & 0.225 & 0.278 & -0.009 & -0.052 & -0.052 & -0.023 & -0.056 & -0.061 & -0.097 & -0.033 & -0.186 & 1 & 0.005 & 0.232 \\
\hline
\end{tabular}




\begin{tabular}{|c|c|c|c|c|c|c|c|c|c|c|c|c|c|c|c|}
\hline & & $<0.001$ & $<0.001$ & 0.408 & $<0.001$ & $<0.001$ & 0.038 & $<0.001$ & $<0.001$ & $<0.001$ & 0.003 & $<0.001$ & & 0.671 & $<0.001$ \\
\hline \multirow[t]{2}{*}{ GrowthSale } & (13) & 0.029 & 0.044 & -0.022 & 0.063 & 0.057 & -0.041 & 0.111 & 0.066 & 0.179 & 0.027 & 0.156 & -0.055 & 1 & -0.178 \\
\hline & & $<0.001$ & $<0.001$ & 0.048 & $<0.001$ & $<0.001$ & $<0.001$ & $<0.001$ & $<0.001$ & $<0.001$ & 0.017 & $<0.001$ & $<0.001$ & & $<0.001$ \\
\hline \multirow[t]{2}{*}{ FirmST } & (14) & 0.153 & 0.178 & 0.009 & -0.123 & -0.073 & -0.066 & -0.076 & -0.139 & -0.254 & -0.062 & -0.344 & 0.354 & -0.119 & 1 \\
\hline & & $<0.001$ & $<0.001$ & 0.406 & $<0.001$ & $<0.001$ & $<0.001$ & $<0.001$ & $<0.001$ & $<0.001$ & $<0.001$ & $<0.001$ & $<0.001$ & $<0.001$ & \\
\hline
\end{tabular}

Upper triangular matrix represents Spearman correlation; lower triangular matrix represents Pearson correlation. Values in italic are probabilities of significances. 
Table 3 Cross-sectional time series regression on earnings management with individual ownership characteristics (OLS)

AdisAccruals is absolute value of discretionary accruals, AccrualQuality is accrual quality, ForeignInv is foreign investment dummy that codes 1 if a firm issued foreign shares and 0 otherwise, StateRatio is state ownership ratio, StateLargest is state control dummy that codes 1 if the state is the largest owner and 0 otherwise, TradeRatio is tradable share ratio. Top5Total is total ownership concentration, Top5Ttrade tradable ownership concentration, FundRatio is institutional ownership ratio, ManagRatio is managerial ownership ratio, LogAsset is logarithm of total assets, Leverage is the ratio of liability to assets, GrowthSale is the growth ratio of annual sales, FrimST is a dummy variable that codes 1 if a firm is designated by CSRC as ST firm and 0 otherwise, IndustryD is industry dummy and YearlyD is year dummy.

\begin{tabular}{|c|c|c|c|c|c|c|c|c|}
\hline \multicolumn{9}{|c|}{ Panel A: Dependent variable is absolute values of discretionary accruals (AdisAccrual) } \\
\hline & Model 1 & Model 2 & Model 3 & Model 4 & Model 5 & Model 6 & Model 7 & Model 8 \\
\hline Intercept & 0.301 & 0.304 & 0.295 & 0.320 & 0.301 & 0.293 & 0.301 & 0.301 \\
\hline & $(14.67 * *)$ & $(14.95 * *)$ & $(14.49 * *)$ & $(15.77 * *)$ & $(14.90 * *)$ & $(14.40 * *)$ & $(14.51 * *)$ & $\left(14.86^{* *}\right)$ \\
\hline ForeignInv & $\begin{array}{c}0.001 \\
(0.15)\end{array}$ & & & & & & & \\
\hline StateRatio & & $\begin{array}{l}0.007 \\
(1.41)\end{array}$ & & & & & & \\
\hline StateLargest & & & $\begin{array}{r}-0.006 \\
(-2.87 * *)\end{array}$ & & & & & \\
\hline TradeRatio & & & & $\begin{array}{r}-0.039 \\
\left(-7.66^{* *}\right)\end{array}$ & & & & \\
\hline Top5Total & & & & & $\begin{array}{r}0.001 \\
(6.37 * *)\end{array}$ & & & \\
\hline Top5Ttrade & & & & & & $\begin{array}{r}-0.001 \\
(-3.24 * *)\end{array}$ & & \\
\hline FundRatio & & & & & & & $\begin{array}{l}-0.001 \\
(-0.07)\end{array}$ & \\
\hline ManagRatio & & & & & & & & $\begin{array}{l}0.077 \\
(1.00)\end{array}$ \\
\hline LogAsset & $\begin{array}{r}-0.010 \\
(-11.33 * *)\end{array}$ & $\begin{array}{r}-0.011 \\
(-11.61 * *)\end{array}$ & $\begin{array}{r}-0.010 \\
\left(-10.95^{* *}\right)\end{array}$ & $\begin{array}{r}-0.010 \\
(-11.24 * *)\end{array}$ & $\begin{array}{r}-0.012 \\
(-12.53 * *)\end{array}$ & $\begin{array}{r}-0.010 \\
(-10.71 * *)\end{array}$ & $\begin{array}{r}-0.010 \\
\left(-11.16^{* *}\right)\end{array}$ & $\begin{array}{r}-0.010 \\
(-11.51 * *)\end{array}$ \\
\hline Leverage & $\begin{array}{r}0.058 \\
(15.25 * *)\end{array}$ & $\begin{array}{r}0.058 \\
(15.31 * *)\end{array}$ & $\begin{array}{r}0.057 \\
(15.07 * *)\end{array}$ & $\begin{array}{r}0.058 \\
(15.22 * *)\end{array}$ & $\begin{array}{r}0.059 \\
(15.60 * *)\end{array}$ & $\begin{array}{r}0.058 \\
\left(15.16^{* *}\right)\end{array}$ & $\begin{array}{r}0.058 \\
(15.25 * *)\end{array}$ & $\begin{array}{r}0.058 \\
(15.27 * *)\end{array}$ \\
\hline GrowthSale & $\begin{array}{r}0.011 \\
(4.99 * *)\end{array}$ & $\begin{array}{r}0.011 \\
(4.96 * *)\end{array}$ & $\begin{array}{r}0.011 \\
(5.02 * *)\end{array}$ & $\begin{array}{r}0.009 \\
(4.24 * *)\end{array}$ & $\begin{array}{r}0.009 \\
(4.39 * *)\end{array}$ & $\begin{array}{r}0.011 \\
(4.91 * *)\end{array}$ & $\begin{array}{r}0.011 \\
\left(5.00^{* *}\right)\end{array}$ & $\begin{array}{r}0.011 \\
(5.01 * *)\end{array}$ \\
\hline FirmST & $\begin{array}{r}0.017 \\
(4.82 * *)\end{array}$ & $\begin{array}{r}0.017 \\
(4.84 * *)\end{array}$ & $\begin{array}{r}0.016 \\
(4.68 * *)\end{array}$ & $\begin{array}{r}0.015 \\
\left(4.35^{* *}\right)\end{array}$ & $\begin{array}{r}0.016 \\
(4.68 * *)\end{array}$ & $\begin{array}{r}0.016 \\
\left(4.66^{* *}\right)\end{array}$ & $\begin{array}{r}0.017 \\
(4.81 * *)\end{array}$ & $\begin{array}{r}0.017 \\
(4.84 * *)\end{array}$ \\
\hline IndustryD & include & include & include & include & include & include & include & include \\
\hline YearlyD & include & include & include & include & include & include & include & include \\
\hline Adjusted & 10.53 & 10.26 & 10.55 & 10.19 & 10.99 & 9.65 & 9.53 & 9.54 \\
\hline R-Square & & & & & & & & \\
\hline
\end{tabular}


Table 3 (continue)

Panel B: Dependent variable is accrual quality (AccrualQuality)

\begin{tabular}{|c|c|c|c|c|c|c|c|c|}
\hline & Model 1 & Model 2 & Model 3 & Model 4 & Model 5 & Model 6 & Model 7 & Model 8 \\
\hline Intercept & 0.200 & 0.197 & 0.190 & 0.202 & 0.195 & 0.194 & 0.199 & 0.195 \\
\hline & $(16.83 * *)$ & $(16.63 * *)$ & $(16.13 * *)$ & $\left(17.06^{* *}\right)$ & $(16.58 * *)$ & $\left(16.36^{* *}\right)$ & $(16.45 * *)$ & $(16.61 * *)$ \\
\hline ForeignInv & $\begin{array}{r}0.005 \\
(2.39 *)\end{array}$ & & & & & & & \\
\hline StateRatio & & $\begin{array}{l}0.022 \\
(0.88)\end{array}$ & & & & & & \\
\hline StateLargest & & & $\begin{array}{r}-0.005 \\
(-3.55 * *)\end{array}$ & & & & & \\
\hline TradeRatio & & & & $\begin{array}{r}-0.015 \\
(-4.09 * *)\end{array}$ & & & & \\
\hline Top5Total & & & & & $\begin{array}{r}0.002 \\
(3.44 * *)\end{array}$ & & & \\
\hline Top5Ttrade & & & & & & $\begin{array}{r}-0.001 \\
\left(-1.67^{\#}\right)\end{array}$ & & \\
\hline FundRatio & & & & & & & $\begin{array}{l}0.001 \\
(1.12)\end{array}$ & \\
\hline ManagRatio & & & & & & & & $\begin{array}{r}0.167 \\
(3.00 * *)\end{array}$ \\
\hline LogAsset & $\begin{array}{r}-0.008 \\
\left(-14.06^{* *}\right)\end{array}$ & $\begin{array}{r}-0.007 \\
\left(-13.75^{* *}\right)\end{array}$ & $\begin{array}{r}-0.007 \\
\left(-12.95^{* *}\right)\end{array}$ & $\begin{array}{r}-0.007 \\
(-13.87 * *)\end{array}$ & $\begin{array}{r}-0.008 \\
(-14.26 * *)\end{array}$ & $\begin{array}{r}-0.007 \\
(-13.54 * *)\end{array}$ & $\begin{array}{r}-0.008 \\
(-13.69 * *)\end{array}$ & $\begin{array}{r}-0.007 \\
(-13.84 * *)\end{array}$ \\
\hline Leverage & $\begin{array}{r}0.037 \\
(17.05 * *)\end{array}$ & $\begin{array}{r}0.037 \\
(17.1 * *)\end{array}$ & $\begin{array}{r}0.037 \\
(16.86 * *)\end{array}$ & $\begin{array}{r}0.037 \\
(16.97 * *)\end{array}$ & $\begin{array}{r}0.038 \\
(17.24 * *)\end{array}$ & $\begin{array}{r}0.037 \\
(17.03 * *)\end{array}$ & $\begin{array}{r}0.037 \\
(17.08 * *)\end{array}$ & $\begin{array}{r}0.037 \\
(17.14 * *)\end{array}$ \\
\hline GrowthSale & $\begin{array}{r}0.009 \\
(7.25 * *)\end{array}$ & $\begin{array}{r}0.009 \\
\left(7.1^{* *}\right)\end{array}$ & $\begin{array}{r}0.009 \\
(7.12 * *)\end{array}$ & $\begin{array}{r}0.008 \\
\left(6.57^{* *}\right)\end{array}$ & $\begin{array}{r}0.008 \\
(6.77 * *)\end{array}$ & $\begin{array}{r}0.009 \\
(7.10\end{array}$ & $\begin{array}{r}0.009 \\
(7.07 * *)\end{array}$ & $\begin{array}{r}0.009 \\
(7.14 * *)\end{array}$ \\
\hline FirmST & $\begin{array}{r}0.011 \\
(5.38 * *)\end{array}$ & $\begin{array}{r}0.011 \\
(5.54 * *)\end{array}$ & $\begin{array}{r}0.010 \\
(5.280\end{array}$ & $\begin{array}{r}0.010 \\
(5.28 * *)\end{array}$ & $\begin{array}{r}0.011 \\
\left(5.44^{* *}\right)\end{array}$ & $\begin{array}{r}0.011 \\
\left(5.49^{* *}\right)\end{array}$ & $\begin{array}{r}0.011 \\
(5.57 * *)\end{array}$ & $\begin{array}{r}0.011 \\
(5.56 * *)\end{array}$ \\
\hline IndustryD & include & include & include & include & include & include & include & include \\
\hline YearlyD & include & include & include & include & include & include & include & include \\
\hline Adjusted & 13.08 & 13.02 & 13.18 & 13.32 & 13.17 & 13.01 & 13.02 & 13.13 \\
\hline R-Square & & & & & & & & \\
\hline
\end{tabular}

Values in parentheses are t-statistics. ${ }^{* *}, *$, and ${ }^{\#}$ indicate significance at $1 \%, 5 \%$ and $10 \%$ respectively. 
Table 4 Cross-sectional time series regression on earnings management (measured by absolute value of discretionary accruals and accruals quality respectively) with ownership characteristics (OLS)

AdisAccruals is absolute value of discretionary accruals, AccrualQuality is accrual quality, ForeignInv is foreign investment dummy that codes 1 if a firm issued foreign shares and 0 otherwise, S StateRatio is state ownership ratio, StateLargest is state control dummy that codes 1 if the state is the largest owner and 0 otherwise, TradeRatio is tradable share ratio. Top5Total is total ownership concentration, Top5Ttrade tradable ownership concentration, FundRatio is institutional ownership ratio, ManagRatio is managerial ownership ratio, LogAsset is logarithm of total assets, Leverage is the ratio of liability to assets, GrowthSale is the growth ratio of annual sales, FrimST is a dummy variable that codes 1 if a firm is designated by CSRC as ST firm and 0 otherwise, IndustryD is industry dummy and YearlyD is year dummy.

\begin{tabular}{|c|c|c|c|c|}
\hline Dependent Variables & $\begin{array}{r}\text { Model } 9 \\
\text { AdisAccrual }\end{array}$ & $\begin{array}{r}\text { Model } 10 \\
\text { AdisAccrual }\end{array}$ & $\begin{array}{c}\text { Model } 11 \\
\text { AccrualQuality }\end{array}$ & $\begin{array}{r}\text { Model } 12 \\
\text { AccrualQuality }\end{array}$ \\
\hline Intercept & $\begin{array}{r}0.312 \\
\left(14.65^{* *}\right)\end{array}$ & $\begin{array}{r}0.294 \\
\left(13.76^{* *}\right)\end{array}$ & $\begin{array}{r}0.206 \\
(16.41 * *)\end{array}$ & $\begin{array}{r}0.203 \\
(16.26 * *)\end{array}$ \\
\hline ForeignInv & $\begin{array}{l}0.001 \\
(0.21)\end{array}$ & $\begin{array}{l}0.001 \\
(0.24)\end{array}$ & $\begin{array}{r}0.006 \\
(2.73 * *)\end{array}$ & $\begin{array}{r}0.005 \\
(2.61 * *)\end{array}$ \\
\hline StateRatio & & $\begin{array}{l}0.001 \\
(0.10)\end{array}$ & & $\begin{array}{r}0.002 \\
(0.76)\end{array}$ \\
\hline StateLargest & $\begin{array}{r}-0.014 \\
(-5.98 * *)\end{array}$ & & $\begin{array}{r}-0.006 \\
(-4.60 * *)\end{array}$ & \\
\hline TradeRatio & $\begin{array}{r}-0.0454 \\
(-6.59 * *)\end{array}$ & & $\begin{array}{r}-0.019 \\
(-3.78 * *)\end{array}$ & \\
\hline Top5Total & $\begin{array}{r}0.001 \\
(2.54 *)\end{array}$ & & $\begin{array}{r}0.001 \\
\left(2.24^{*}\right)\end{array}$ & \\
\hline Top5Ttrade & & $\begin{array}{r}-0.001 \\
(-2.91 * *)\end{array}$ & & $\begin{array}{l}-0.001 \\
\left(-1.89^{\#}\right)\end{array}$ \\
\hline FundRatio & $\begin{array}{l}0.001 \\
(0.66)\end{array}$ & $\begin{array}{l}0.001 \\
(0.13)\end{array}$ & $\begin{array}{l}0.001 \\
(1.55)\end{array}$ & $\begin{array}{r}0.001 \\
(1.24)\end{array}$ \\
\hline ManagRatio & $\begin{array}{l}0.048 \\
(0.62)\end{array}$ & $\begin{array}{l}0.082 \\
(1.06)\end{array}$ & $\begin{array}{l}0.148 \\
(2.65)\end{array}$ & $\begin{array}{r}0.168 \\
(3.00 * *)\end{array}$ \\
\hline LogAsset & $\begin{array}{r}-0.010 \\
(-9.87 * *)\end{array}$ & $\begin{array}{r}-0.010 \\
(-10.06 * *)\end{array}$ & $\begin{array}{r}-0.007 \\
(-12.72 * *)\end{array}$ & $\begin{array}{r}-0.008 \\
(-13.42 * *)\end{array}$ \\
\hline Leverage & $\begin{array}{r}0.057 \\
(14.89 * *)\end{array}$ & $\begin{array}{r}0.058 \\
\left(15.13^{* *}\right)\end{array}$ & $\begin{array}{r}0.036 \\
(16.61 * *)\end{array}$ & $\begin{array}{r}0.037 \\
(17.04 * *)\end{array}$ \\
\hline GrowthSale & $\begin{array}{r}0.008 \\
(3.91 * *)\end{array}$ & $\begin{array}{r}0.011 \\
(4.49 * *)\end{array}$ & $\begin{array}{r}0.008 \\
(6.45 * *)\end{array}$ & $\begin{array}{r}0.009 \\
(7.13 * *)\end{array}$ \\
\hline FirmST & $\begin{array}{r}0.014 \\
(3.96 * *)\end{array}$ & $\begin{array}{r}0.016 \\
(4.66 * *)\end{array}$ & $\begin{array}{r}0.010 \\
(4.83 * *)\end{array}$ & $\begin{array}{r}0.011 \\
(5.44 * *)\end{array}$ \\
\hline $\begin{array}{l}\text { IndustryD } \\
\text { YearlyD }\end{array}$ & $\begin{array}{l}\text { include } \\
\text { include }\end{array}$ & $\begin{array}{l}\text { include } \\
\text { include }\end{array}$ & $\begin{array}{l}\text { include } \\
\text { include }\end{array}$ & $\begin{array}{l}\text { include } \\
\text { include }\end{array}$ \\
\hline Adjusted R-Square & 10.61 & 8.62 & 13.70 & 13.2 \\
\hline
\end{tabular}

Values in parentheses are t-statistics. **, *, and ${ }^{\#}$ indicate significance at $1 \%, 5 \%$ and $10 \%$ respectively. When a coefficient is 0.001 or -0.001 , it is most likely the actual value is smaller than 0.001 in absolute value. We report it as 0.001 or -0.001 to avoid the confusion with value of zero. The 0.001 and -0.001 can be thought very weak in determination that is close to zero. 
Table 5 Cross-sectional time series regression on earnings management (measured by absolute value of discretionary accruals and accruals quality respectively) with ownership characteristics (2SLS)

AdisAccruals is absolute value of discretionary accruals, AccrualQuality is accrual quality, ForeignInv is foreign investment dummy that codes 1 if a firm issued foreign shares and 0 otherwise, StateRatio is state ownership ratio, StateLargest is state control dummy that codes 1 if the state is the largest owner and 0 otherwise, TradeRatio is tradable share ratio. Top5Total is total ownership concentration, Top5Ttrade tradable ownership concentration, FundRatio is institutional ownership ratio, ManagRatio is managerial ownership ratio, LogAsset is logarithm of total assets, Leverage is the ratio of liability to assets, GrowthSale is the growth ratio of annual sales, FrimST is a dummy variable that codes 1 if a firm is designated by CSRC as ST firm and 0 otherwise, IndustryD is industry dummy and YearlyD is year dummy.

\begin{tabular}{|c|c|c|c|c|}
\hline Dependent Variables & $\begin{array}{r}\text { Model } 13 \\
\text { AdisAccrual }\end{array}$ & $\begin{array}{r}\text { Model } 14 \\
\text { AdisAccrual }\end{array}$ & $\begin{array}{r}\text { Model } 15 \\
\text { AccrualQuality }\end{array}$ & $\begin{array}{r}\text { Model } 16 \\
\text { AccrualQuality }\end{array}$ \\
\hline \multirow[t]{2}{*}{ Intercept } & 0.466 & 0.462 & 0.287 & 0.286 \\
\hline & $(14.56 * *)$ & $\left(14.45^{* *}\right)$ & $(15.18 * *)$ & $(15.09 * *)$ \\
\hline \multirow[t]{2}{*}{ ForeignInv } & 0.001 & 0.001 & 0.005 & 0.005 \\
\hline & $(0.13)$ & $(0.33)$ & $(2.42 *)$ & $(2.21 *)$ \\
\hline \multirow[t]{2}{*}{ StateRatio } & & 0.010 & & -0.020 \\
\hline & & $(0.016)$ & & $(-0.65)$ \\
\hline \multirow[t]{2}{*}{ StateLargest } & -0.014 & & -0.008 & \\
\hline & $(-5.89 * *)$ & & $(-5.57 * *)$ & \\
\hline \multirow[t]{2}{*}{ TradeRatio } & -0.048 & & -0.026 & \\
\hline & $\left(-7.06^{* *}\right)$ & & $(-5.14 * *)$ & \\
\hline \multirow[t]{2}{*}{ Top5Total } & 0.001 & & 0.001 & \\
\hline & $\left(1.94^{\#}\right)$ & & $\left(+1.76^{\#}\right)$ & \\
\hline \multirow[t]{2}{*}{ Top5Ttrade } & & -0.001 & & -0.001 \\
\hline & & $(-3.05 * *)$ & & $(-1.97 *)$ \\
\hline \multirow[t]{2}{*}{ FundRatio } & 0.001 & 0.001 & 0.001 & 0.001 \\
\hline & $(1.2)$ & $(0.65)$ & $(0.73)$ & $(0.35)$ \\
\hline \multirow[t]{2}{*}{ ManagRatio } & 0.025 & 0.057 & 0.131 & 0.057 \\
\hline & $(0.32)$ & $(0.73)$ & $(2.29 *)$ & $(2.63 * *)$ \\
\hline \multirow[t]{2}{*}{ LogAsset } & -0.016 & -0.017 & -0.009 & -0.010 \\
\hline & $(-12.32 * *)$ & $(-13.04 * *)$ & $(-12.14 * *)$ & $(-13.13 * *)$ \\
\hline \multirow[t]{2}{*}{ Leverage } & 0.040 & 0.035 & -0.004 & -0.006 \\
\hline & $(3.43 * *)$ & $(3.05 * *)$ & $\left(+1.64^{\#}\right)$ & $\left(+1.90^{\#}\right)$ \\
\hline \multirow[t]{2}{*}{ GrowthSale } & 0.009 & 0.011 & 0.007 & 0.008 \\
\hline & $(4.17 * *)$ & $(5.04 * *)$ & $(5.43 * *)$ & $(5.98 * *)$ \\
\hline \multirow[t]{2}{*}{ FirmST } & 0.025 & 0.028 & 0.019 & 0.021 \\
\hline & $(7.29 * *)$ & $(8.18 * *)$ & $(9.74 * *)$ & $(10.61 * *)$ \\
\hline IndustryD & include & include & include & include \\
\hline YearlyD & include & include & include & include \\
\hline Adjusted R-Square & 9.78 & 8.78 & 9.96 & 9.26 \\
\hline
\end{tabular}

Values in parentheses are t-statistics. **, *, and ${ }^{\#}$ indicate significance at $1 \%, 5 \%$ and $10 \%$ respectively. When a coefficient is 0.001 or -0.001 , it is most likely the actual value is smaller than 0.001 in absolute value. We report it as 0.001 or -0.001 to avoid the confusion with value of zero. The 0.001 and -0.001 can be thought very weak in determination that is close to zero. 